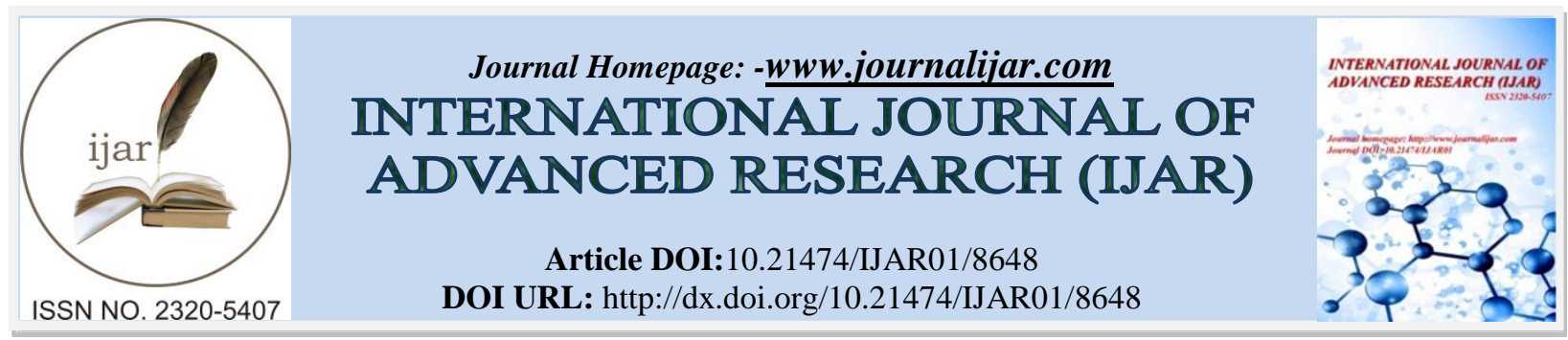

RESEARCH ARTICLE

\title{
A STUDY TO ASSESS THE EFFECTIVENESS OF STRUCTURED TEACHING PROGRAMME ON KNOWLEDGE REGARDING PSYCHOLOGICAL SYMPTOMS OF DEPRESSION AMONG MENOPAUSAL WOMEN IN SELECTED VILLAGE AT COIMBATORE.
}

Principal \& HOD- Department of OBG Nursing.

2. M.Sc(N),OBG, Lecturer Texcity College of Nursing, Coimbatore-641023.

\section{Manuscript Info}

\section{Manuscript History}

Received: 09 January 2019

Final Accepted: 11 February 2019

Published: March 2019

Key words:-

Depression,Menopausal women.

\begin{abstract}
The study was undertaken to assess the effectiveness of structured teaching programme on knowledge regarding psychological symptoms of depression among menopausal women. The research design used for this study was quantitative experimental research design. The result shows that majority of the samples $24(40 \%)$ had inadequate knowledge, 35(58.4\%) had moderate knowledge, 1(1.6\%) had adequate knowledge during pre test, But after the structured teaching programme during the post test, majority of the samples $55(91.7 \%)$ had adequate knowledge, 5(8.3\%) had moderate knowledge and none of them had inadequate knowledge. The result revealed that after structured teaching programme the level of knowledge was increased which was evidenced by improved post test level of knowledge score. The obtained " $t$ " value was 21.8 was more than the table value and significant at $p<0.05$ level. Hence the stated hypothesis was accepted and it was informed that structured teaching programme was effective in improving the knowledge level of psychological symptom of depression among menopausal women
\end{abstract}

Copy Right, IJAR, 2019,. All rights reserved.

\section{Introduction:-}

Menarche and menopause are the turning point in the life of a woman. "Menopause is a stage of life not a disease". Menopause is the cessation of a women's reproductive ability, the opposite of menarche. Menopause is usually a natural changes, it typically occurs in women during the age of 40-50years.

Depression is the feeling of extreme sadness lasting for more than two weeks, often with no specific cause that can be identified, and which interferes with everyday life. Depression can be accompanied by suicidal thoughts, if you are continually feeling worthless, having changes in your sleeping and eating patterns, these may also be indicators of depression.

Women are often at increased risk for depression when they reach midlife. The reasons are unclear, but scientists think it may be related to a personal or family history of depression, and/or to the life stressors and role changes that come with middle age. 
Menopause is defined by the World Health Organization. The permanent cessation of menstrual cycle that occurs naturally or is induced by surgery, chemotherapy, or radiation. Natural menopause is recognized after 12 consecutive months without menstrual cycle that are not associated with a physiologic (e.g., lactation) or pathologic cause. This can be divided into three stages, premenopausal, perimenopausal and postmenopausal

Depression is a common mental disorder; it is a state of low mood and aversion to activity or apathy that can affect a person's thoughts, behavior, feelings, and sense of well-being. People with a depressed mood can feel sad, tiredness, poor concentration, loss of interest, anxious, empty, hopeless, helpless, worthless, guilty, irritable, angry, ashamed, or restless.

Menopause is a normal part of the age process. Follicle stimulating hormones (FSH) and luteinizing (LH) hormones are secreted by the pituitary gland as part of the normal menstrual cycle. They stimulate the ovary to produce estrogen and progesterone and to release an egg. As women ages, her ovaries don't respond to FHS or LH as strongly as they use. Over time, less and less estrogen and progesterone are produced and the women stops releasing eggs.

This decrease in hormones, especially estrogen production, effects on a woman's body and mind, and is often the underlying cause of depression experienced during menopause.

\section{Statement Of The Problem}

"A study to assess the effectiveness of structured teaching programme on knowledge regarding psychological symptoms of depression among menopausal women in selected village at Coimbatore".

\section{Objectives:-}

1. To assess the existing knowledge regarding psychological symptoms of depression among menopausal women.

2. To identify the presence of psychological symptoms of depression among menopausal women.

3. To administered a structure teaching program on knowledge regarding psychological symptoms of depression among menopausal women.

4. To reassess the knowledge regarding psychological symptoms of depression among the menopausal women in term of increase in knowledge.

5. To find out the association between knowledge regarding psychological symptoms of depression among menopausal women with their selected demographic variables.

\section{Hypothesis}

1. $\mathbf{H}_{\mathbf{1}}$ - The mean post test knowledge score will be significantly higher than Mean Pretest knowledge level of the women.

2. $\mathbf{H}_{2}$. There will be significant association between the knowledge of Psychological symptoms of depression with their selected demographic variables.

\section{Assumptions}

1. Women may have some knowledge of menopause.

2. Women may have willingly participate and give reliable information needed for the study.

3. Menopausal women may have some knowledge regarding psychological changes during menopause.

4. Planned teaching programme may improve the knowledge level of menopausal women regarding psychological changes during menopause. 


\section{Research Methodology:-}

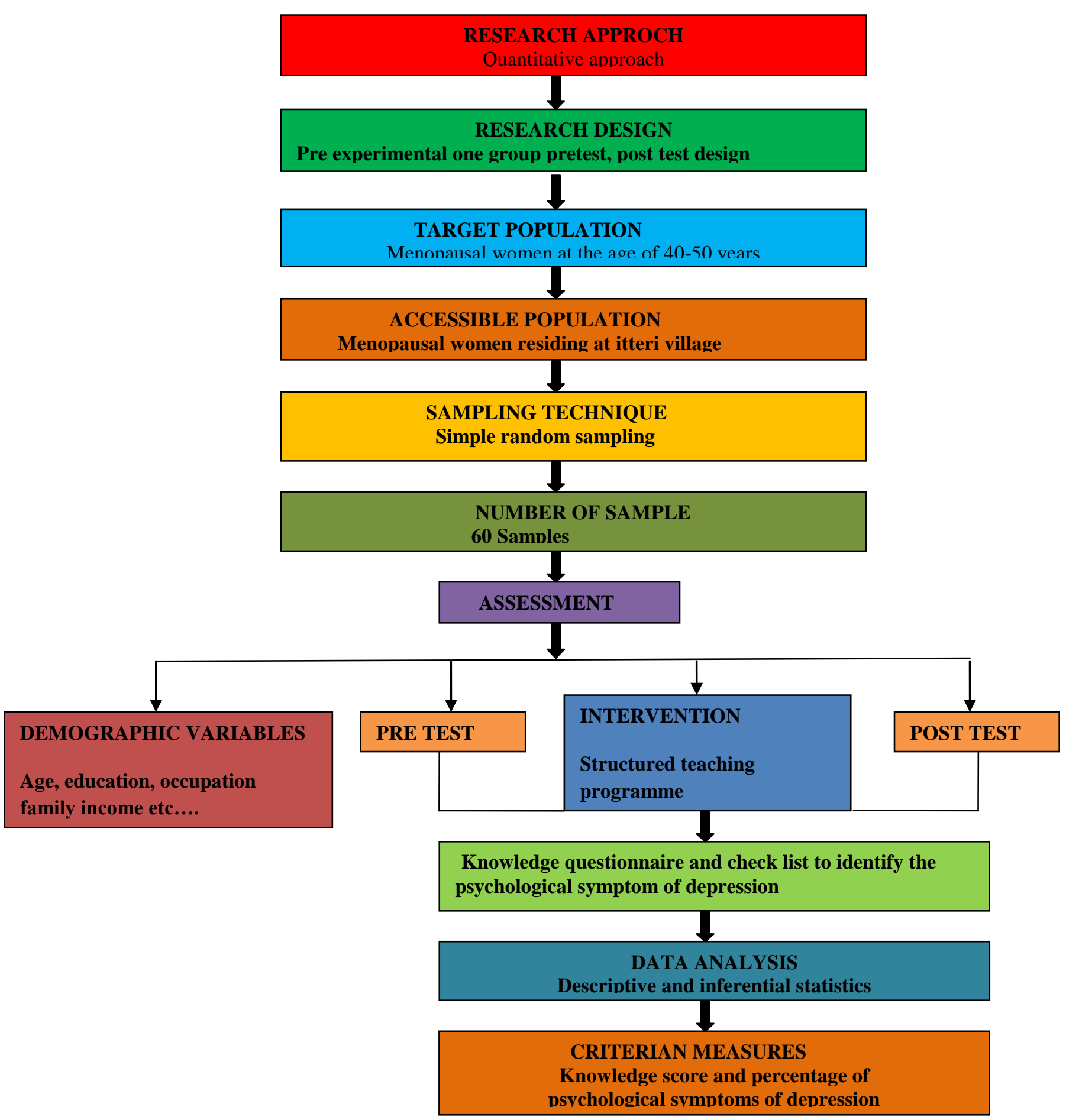

\section{Result and Conclusion:-}

The findings are tabulated and analyses are interpreted as follows 
Table 1:-Distribution of samples according to knowledge level in pretest and post test

\begin{tabular}{|l|l|c|c|c|c|}
\hline \multirow{2}{*}{ S.No. } & Level of knowledge & \multicolumn{2}{|l|}{ Pre test } & Post test \\
\cline { 3 - 6 } & $\begin{array}{c}\text { Frequency } \\
(\mathbf{f})\end{array}$ & $\begin{array}{c}\text { Percentage } \\
(\%)\end{array}$ & $\begin{array}{c}\text { Frequency } \\
(\mathbf{f})\end{array}$ & $\begin{array}{c}\text { Percentage } \\
(\%)\end{array}$ \\
\hline 1. & Adequate & 1 & 1.6 & 55 & 91.7 \\
2. & Moderate & 35 & 58.4 & 5 & 8.3 \\
3. & Inadequate & 24 & 40 & 0 & 0 \\
\hline
\end{tabular}

The data presented in Table: 1 shows that, majority of the samples 24(40\%) had inadequate knowledge, 35(58.4\%) had moderate knowledge, 1(1.6\%) had adequate knowledge during pre test, But after the structured teaching programme during the post test, majority of the samples $55(91.7 \%)$ had adequate knowledge, $5(8.3 \%)$ had moderate knowledge and none of them had inadequate knowledge. The result revealed that after structured teaching programme the level of knowledge was increased which was evidenced by improved post test level of knowledge score

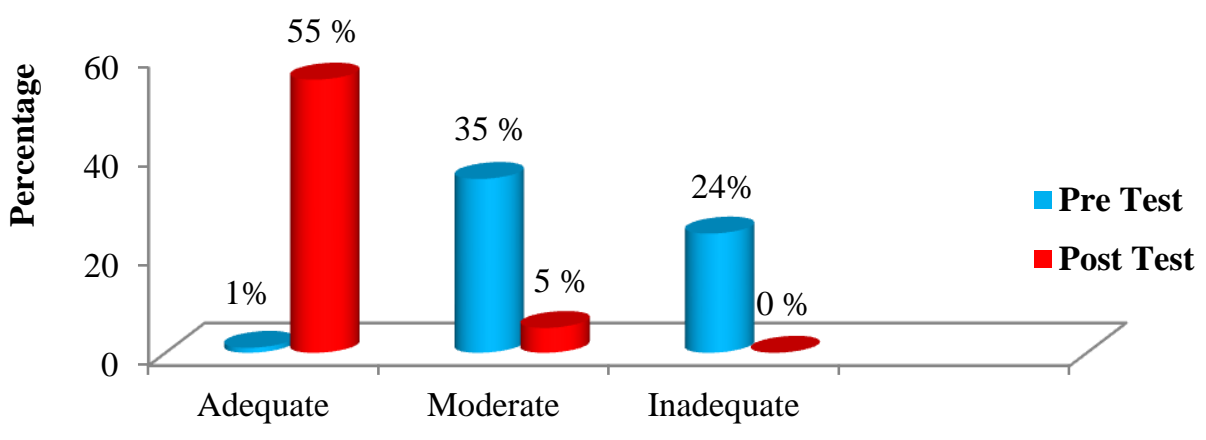

Table 2:-Mean, Median, and Standard deviation and ' $t$ ' value of pretest and posttestLevel of knowledge among

\begin{tabular}{|c|c|c|c|c|c|}
\hline S.NO & Variables & Mean & $\begin{array}{c}\text { Standard } \\
\text { Deviation }\end{array}$ & $\begin{array}{r}\text { Mean } \\
\text { Difference }\end{array}$ & "t't" value \\
\hline 1. & Pre test & 11 & 3.3 & \multirow{2}{*}{13.1} & \multirow{2}{*}{21.8} \\
\hline 2. & Post test & 24.1 & 2.4 & & \\
\hline
\end{tabular}

* Significant at $\mathrm{p}<0.05$ level

Table: 2 Revealed that, the obtained " $\mathrm{t}$ " value was 21.8 was more than the table value and significant at $\mathrm{p}<0.05$ level. Hence the stated hypothesis was accepted and it was informed that structured teaching programme was effective in improving the knowledge level of psychological symptom of depression among menopausal women. 


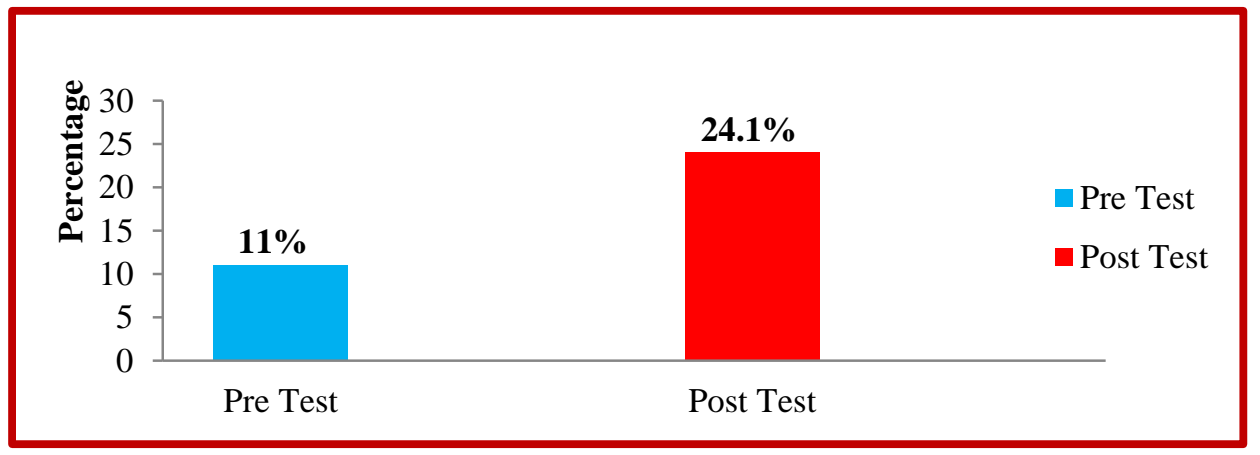

\section{Conclusion:-}

Based on the analysis of the findings the following conclusion was drawn. The study proved that, majority of the samples had inadequate knowledge regarding psychological symptom of depression among menopausal women structured teaching programme was helpful to improve the knowledge level of samples.

\section{Limitation}

1. The sample size was only 60 , hence the findings could not be generalized.

2. The purposive sampling technique does not give a respective sample.

\section{Recommendations:-}

1. Similar kind of study can be done in various settings like women those who are working in mills, factories in Coimbatore. And class III workers of any government organization.

2. Study can be conducted by using different teaching modules regarding psychological symptom of depression among menopausal women.

3. Comparative study can be conducted by using two different interventions to improve the knowledge of menopausal women.

\section{Reference:-}

1. Annamma Jacab. " Manual of Midwives"4 th edition, Jaypee publication, 2015, Page no:n903-906

2. Adele pillitteri "Maternal and Child Health Nursing"3 rd edition, Lippincott publication, 1999, page, no.70 83.

3. Basavanthapa.B.T "Nursing Research" $2^{\text {nd }}$ edition, New Delhi, Jaypee Brothers Medical Publication, 2004, Page No: $172-174$

4. D.C.Dutta's "Text Book of Obstetrics" $6^{\text {th }}$ edition, New central book agency, 2004, page. No: $324-330$

5. Myles's "Text Book of Midwives" $14^{\text {th }}$ edition, Elsevier publication (p) ltd, 2013, page. No: 552- 558.

6. Neema Bhaskeran "Midwifery and Obstetrical Nursing"' $1^{\text {st }}$ edition, EMMESS publication, 2012, page. No : 628 $-635$

7. Nisha Clement. "General Nusing \& Miwifery" $2^{\text {nd }}$ edition,Jaypee publication,2014,Page no 221-223

8. Akoijam mamata devi.M. "International Journal Advance In Nursing Management” Vol - 3, Jan - March 2015. Page no : 7

9. Amaal Mohamed Ahmed El-Zeftawy. "IOSR Journal of Nursing and Health Science" Volume 4, May- Jun. 2015, Page no: 51-63

10. Anita H. "Primary Care Companion J Clinic Psychiatry " Vol-2. 2010, page no : 1-21

11. Ensieh Noroozi. "Journal of education and health promotion" Vol 2, 2013,page no : 1

12. Rukmani.R. "TNNMC - Journal of obstetrics and Gynaecological nursing", Vol -2, Jul - Dec 2014, page no : 19

13. S.Kala Barathi. "IOSR Journal of Nursing and Health Science" Volume 3, Mar-Apr. 2014, Page no: 33-37

14. S.Sujithra. "IOSR Journal of Nursing and Health Science" Volume 3, Nov. - Dec. 2013, Page no: 01-05.

15. VeenaRajput. "Asian Journal of Nursing Education and Research" Volume No : 2, 2012, page no 1-2

16. V. Indra. "Asian Journal of Nursing Research” Volume 6, 2016, page no: 1 